\title{
关于水利建筑工程造价控制的探讨
}

\author{
江舟 \\ 清远市清城区水务局 \\ DOI:10.18686/bd.v2i3.1293
}

[摘 要] 水利建筑工程建设是国家基础设施建设的重要内容, 水利建筑工程造价控制是动态工程,其贯穿于水利工程项目 建设的全过程。为了提高水利建筑工程的经济效益, 本文阐述了水利建筑工程造价控制的重要意义及其造价特征, 对水利建 筑工程造价控制存在的主要问题及其策略进行了探讨分析, 旨在保障水利建筑工程建设的顺利进行。

[关键词] 水利建筑工程; 造价控制; 意义; 特征; 问题; 策略

水利建筑工程造价控制不仅是指在设计和施工全工程 中把水利工程项目的造价控制在预先确定的合理限额之 内,更重要的在于合理使用人力、物力和财力,并且其是国民 经济发展的重要基础,基于此,以下就水利建筑工程造价控 制存在的主要问题及其策略进行了探讨分析。

\section{1 水利建筑工程造价控制的重要意义}

水利建筑工程造价控制属于水利工程成本控制的一项 重要内容, 其是通过科学的分析方法对整个工程建设的各 个阶段进行控制, 从而使水利工程建设得以顺利进行。水利 工程各阶段形成造价之间的关系是前者制约后者、后者补 充前者。水利工程建设过程中,所需资金的筹集必须依赖于 整个工程造价的控制, 只有根据实际需要做出了资金需求, 各级政府才能给予财政投资, 才能筹集到足够的资金以保 证工程建设的顺利进行, 从这个意义上来说, 水利建筑工程 造价控制是有效拓宽筹集资金的重要渠道; 同时,水利工程 项目建设主要立足于该项目的工程造价控制, 在对水利建 设项目进行投资时, 相关部门一般是先进行可行性分析, 再 将整个工程项目的范围、规则以及设计标准等置于一定的 预设范围内, 最后在对经济需求与技术两方面进行综合权 衡下做出正确的决策, 这是水利工程建设目标得以实现的 关键所在。

\section{2 水利建筑工程造价的主要特征}

水利建筑工程造价的特征主要表现为:(1) 水利工程建 设的影响因素较多, 其工程造价也涉及多个不同行业的知 识和相关规定, 而这些涉及不同行业的分块投资都要合理 而有序地组合到一个水利建筑工程造价中, 并要统筹考虑 互相之间的平衡和关联。(2)水利工程建设的周期长, 从工程 前期的准备阶段到工程建成完工, 一般均要经过项目建议 书审议阶段、可行性研究阶段、设计阶段、施工准备阶段、建 设实施阶段、生产准备阶段、竣工验收阶段、后评价阶段,同 其他工程相比, 建设阶段较多, 历时较长, 施工期长达几年甚 至十几年。针对不同的建设阶段, 要编制相应的工程造价, 且 各阶段的编制依据及编制方法均有所差别。(3)水利工程建 设的区域跨度较大, 不同于其他工程,一个大型的水利工程, 其建筑群体的范围常常涉及不同的省市或地区, 根据地区
性特点,各地区的水利建筑工程造价的差别较大, 因而仅一 个水利建筑工程造价的编制就要求编制人员要收集并熟悉 各地区的政策、法规及相关规定。

\section{3 水利建筑工程造价控制存在的主要问题分析}

水利建筑工程造价控制存在的问题主要有:(1) 设计方 案不合理的问题。一部分设计单位设计出来的方案粗略, 实 用性较低, 他们在设计水利工程时, 常常忽视设计各个阶段 的造价指标, 有的设计追求新型和新颖性的方案, 而不考虑 方案的实用性和安全系数, 导致部分水利工程的寿命不长, 但是成本和投资却很高。(2)建设单位缺乏责任心与风险意 识的问题。一些建设单位缺乏责任心和风险意识, 不能合理 地决策工程建设, 对预算工程项目的建设成本与效益也不 能科学地规划。有的为了申请同意甚至在对项目可行性分 析的过程中弄虚作假,忽视工程的时效性。(3)造价管理单位 的职能没有落实的问题。有的造价监理公司或咨询公司的 顾问和工作人员没有达到职位所要求素质和能力标准, 导 致造价管理单位的作用和职能并没有真正发挥出来。有些 造价管理咨询机构人员欠缺实践经验，遇到风险不会主动 规避, 不能有效控制造价, 有的甚至与施工方和建设单位串 通一起谋私利,让水利工程投资失控现象更严重。

\section{4 加强水利建筑工程造价控制的策略}

4.1 投资决策阶段造价控制的策略。投资决策阶段是水 利建筑工程造价控制的关键, 应用科学的投资管理方法, 完 善和规划投资的最终决策。笔者认为需要做好以下几点: 第 一,对水利工程的实施需要做好详尽的基础资料准备,并确 保收集的资料的完整性、准确性。满意预测项目的投资,对 诸多基础数据进行归纳整理,如工程的地理位置、地质地貌 情况、自然资源储备、工程中主要设备材质的报价等等方 面,为施工顺利开展奠定基础,进行基础的设计、分析经济状 况提供真实具体的数据信息, 工程造价人员对资料整合根 据数据资料的完整性、可靠性、全面性、准确性进行分析, 实 现预测和分析的准确性。第二,对市场进行整体的调查和具 体研究是实现项目基础建设的砥柱力量。市场调研具备的 要素是真实性、全面性、适应性, 要了解经济体制各阶段发 展的规划和国家对相关产业政策的发展趋势的追踪, 以及 
掌握相关项目的建设状况等。估算指标不是随便制定的应 该以投资的目的、指标、规模、要求等方面因素作为参考,保 证估算的价值和质量。投资技术人员对拟定的信息进行系 统全面的调查, 并通过整体的分析和合适的处理方式来证 明完成项目的具体建设的可行性和重要性。

4.2 设计阶段造价控制的策略。水利工程设计阶段造价 控制策略主要体现在以下几方面:(1) 大力推行工程设计招 标制度, 通过公开、公平的竞争, 促进设计单位自觉按建筑设 计要求提交实用、美观、安全、经济的设计方案。(2)推行限额 设计, 在整个设计过程中, 设计人员要经常检查本专业的工 程费用，切实作好控制造价工作。(3)造价咨询专家提前介人 优化设计方案,造价咨询专家可以在方案设计阶段,利用同 类建筑的技术经济指标, 对拟建筑按照不同的设计方案,根 据现有的价格水平进行分析、比较。(4)改进设计取费办法, 实行在现有收费办法的基础上加人节约投资提成，投资超 出扣除一定比例设计的收费办法, 就会使设计单位和设计 人员的设计思想大大改观,充分显出经济杜杆的力量,使设 计和工程投资有机地结合起来。(5)推广标准设计,推广标准 设计有利于较大幅度降低工程造价, 可以节约设计费用, 大 大加快提供设计图纸的速度,缩短设计周期,构件预制厂生 产标准件,能使工艺定型,而且容易使生产均衡和提高劳动 生产率以及统一配料, 节约材料, 有利于构配件成本的大幅 度降低。

4.3 施工阶段造价控制的策略。水利工程建设施工阶段 的造价控制非常重要,主要表现为:(1)严格控制设计变更,减 少工程索赔。在水利工程建设施工过程中,由于勘察设计的 问题, 使得施工中出现招标文件没有提出或者估算不准确 的工程量,结果不得不改变施工项目或者增减工程量,再一 个由于水利工程施工会受到现场条件以及气候条件的影 响,从而引起停工或者延长工期等,另外,在实际的施工过程 中, 索赔问题是经常发生并随处可见的正常现象, 比如说双 方当事人中有一方不按照既定的义务或者对方做出有损权 利人行为的时候, 要求进行的补偿等等都会引起水利工程 项目的成本超出原来的预算, 在对于工程造价的控制上有 一定的阻碍,所以必须在水利工程变更问题上把好关,时刻
关注没有完成的工程支出的影响和对工期的影响。(2)技术 与经济相结合, 从经济和技术两个方面来对投资的进行有 效控制。长期以来,在水利工程领域中,技术和经济往往没有 很好的结合起来,走在一条计划经济的老路上,然而事实证 明,技术与经济相结合才是控制工程造价最有利的手段。因 此在技术上我们应集思广益, 采用新工艺、新材料和新办法 等,经济上减少诸如企业管理费、现场经费等支出来实现降 低造价的目的。做好现场的材料设备管理,合理摆放,减少搬 运及损耗。

4.4 竣工阶段造价控制的策略。水利工程建设完成后, 其造价控制主要表现为建设项目竣工决算。对整个水利工 程所涉及到的全部费用支出进行成本核算, 编制出竣工决 算表,对工程造价进行比较分析。工作中,要从工程建设的 “工期、质量、投资”这几个方面逐一的审查实际情况, 审查 水利工程项目的建设成本是否超过计划, 水利工程建设质 量是否符合设计目标, 同时还要审查水利工程项目中的各 个子项目的交付是否完整真实, 是否按施工图纸施工, 是否 存在偷工减料和未完工程的现象。

\section{5 结束语}

综上所述,水利工程建设事关国计民生,事关人民群众 的生命财产安全, 对我国社会经济发展和社会安定具有重 要的作用。为了提高水利建筑工程的经济效益, 因此必须加 强水利建筑工程建设各个阶段造价的控制。

\section{参考文献:}

[1]罗萍.水利工程施工造价与成本管理 $[J]$. 黑龙江水 利科技,2015,43(07):157-158.

[2]祁海燕.浅谈水利工程项目造价管理与控制 [J].水 利技术监督, 2017,25(03): 46-47+100.

[3]徐娇. 浅谈水利工程造价控制 [J].建材与装饰, 2017, (04):126-127.

[4]宋清樹. 论审计对水利工程建设各阶段造价的控制 [J].南方农机,2017,48(22):123.

[5]崔琬茁.水利工程造价影响因素分析与控制措施探 讨[J].中国高新区,2018,(01):221。 